\title{
The Most Difficult Basic Skill Faced by Learners of English in First Year Undergraduate Classes at UEA/Bukavu, DR Congo
}

\author{
Ct Buhendwa Rubango Jeff \\ UEA, Norwich, England \\ Email: buhendwajeff@gmail.com
}

How to cite this paper: Jeff, C. B. R. (2019). The Most Difficult Basic Skill Faced by Learners of English in First Year Undergraduate Classes at UEA/Bukavu, DR Congo. Creative Education, 10, 464-474. https://doi.org/10.4236/ce.2019.102033

Received: December 25, 2018

Accepted: February 25, 2019

Published: February 28, 2019

Copyright $\odot 2019$ by author(s) and Scientific Research Publishing Inc. This work is licensed under the Creative Commons Attribution International License (CC BY 4.0).

http://creativecommons.org/licenses/by/4.0/

\begin{abstract}
This article pursues three objectives: firstly, it aims at identifying the most difficult basic skill faced by learners of English in first year undergraduate classes at UEA, one of the major universities in Bukavu, DR Congo. Secondly, the author aims to find out its factors and thirdly, to propose possible solutions to such a problem. The study focused on 750 learners (259 female plus 491 male) of English at UEA. The research was conducted in the first semester of the academic year 2015-2016. The sample was randomly selected in all the faculties of UEA. The research instruments were a placement test, and class observations. Analytical and comparative methods were used to investigate on students' English basic skill difficulties. The collected data were transformed into tables and calculated in percentage to facilitate the interpretation. The findings of the study revealed that speaking skill was the biggest problem (with the highest below average rate: 14.27\%). Its main factors were low-backgrounds of learners, shyness and lack of interest in English language activities. Some strategies to tackle this challenge were notably: recitation of memory verses related to different fields of studies (Agronomy, Economics, Theology, Social Sciences and Medicine) at UEA, inspiring shy students self-confidence and self-esteem, making presentations in classrooms and in English clubs, attending the Language Resource Centre for practice, answering oral text comprehension in full and correct sentences, spoken English practice by holding dialogues and debates with classmates.
\end{abstract}

\section{Keywords}

Most Difficult Basic Skill, Learners of English, UEA

\section{Introduction}

A growing number of universities require English for admission or graduation, 
and many now offer degree programs entirely in English to compete with the top ranked institutions in the US. and the UK. In addition to all the young people learning English through public education, the private English instruction sector is an estimated 50 billion dollar industry. Indeed, it has been proposed that within the next decade as many as two billion people will be learning English at any given time

(https://www.teachingenglish.org.uk/sites/teacheng/files/pub_learning-elt-future .pdf, downloaded on March 14, 2016).

English is the main language of science and technology in the world and its spread is advancing in many countries and regions where it has not been traditionally spoken as in DR Congo.

The DR Congo Government also decided to enhance learning and teaching of English by publishing on September 30, 2015 an Academic Instruction (N017/MINESU/CABMIN/TMF/SMM/2015, p.10 paragraph 1.10). The latter aims at reminding the Heads of Public and Private Schools involved in Higher Academic Institutions and University Education to teach English systematically in all classes from the Undergraduate to the Graduate Cycles.

In spite of such a great importance of English in modern world, most people do not care about it. Unfortunately, some students fail in English assignments because they do not understand this language either. All over the world some learners and teachers of English face problems as it was the case in Thailand (Noom-Ura, 2013: p. 5), in Taiwan (Chang, 2011: p. 7), in India (Reddy, 2012: p. 782), in America (Garrett, 2006: p. 5), and in Nigeria (Oluwayemisi, 2015: p. 28).

As French speaking people, students at the Evangelical University in Africa respectively learn English as a Foreign Language. Apart from mother tongues, French is known as an official and administration language. It is equally used for learning and teaching subject disciplines at elementary schools, at high schools and universities. Swahili, Lingala, Kikongo and Tshiluba are the four national languages of the DR Congo.

(https://en.wikipedia.org/wiki/Languages_of_the_Democratic_Republic_of_the_ Congo, downloaded on March 21 $\left.1^{\text {st }}, 2016\right)$. These functional languages are often used and heard each or some in different regions depending on the places where the schools are found. English language seems to be neglected. In this way, students think that English is too difficult to understand, to speak, to write and to read.

The goal of writing assignments is not only to transform students into better writers, but into better biologists, political scientists, or sociologists (Mintz, n.d.: p. 39). In spite of this goal, the overall expectations of learning and teaching English are not encouraging. Some students often answer questions by "yes" or "no" without understanding what is really said. And others admit they understand teacher's questions but they are not able to answer in English. Most fresh students are from different High Schools and with low-backgrounds of English register for the first undergraduate training programme which is overcrowded at UEA. 
Indeed, learning English in the first year undergraduate classes during the first semester/2015-2016 was a tough task. Students often encountered difficulties in listening, speaking, writing and reading English. This situation led us to ask three questions in this investigation: Which English basic skill is the most difficult for the first year undergraduate students at different levels at UEA? What can be its factors and how to tackle it?

The following hypotheses correspond to these questions.

It is hypothesized that speaking skill is their biggest problem. Its factors might be low-backgrounds of learners, shyness and lack of interest in English language activities. As possible solutions, different educational partners are given some recommendations to tackle this challenge confronted by learners of English in first year undergraduate classes at different levels at UEA.

As objectives, this research project mainly aims to investigate the most difficult basic skill faced by learners of English at different levels in first year undergraduate classes at UEA in the first semester/2015-2016; to find out some factors and propose strategies to tackle this challenge.

The study was conducted at the Evangelical University in Africa (UEA) which is the writer's business and the first one in Bukavu to divide first year undergraduate classes into different levels for an efficient learning English. As the most overcrowded classes, the latter got a good attendance to make the sample of this study. The research was conducted in the first semester of the academic year 2015-2016 because during this time, all of the five teachers of English, included the present researcher and author, were teaching and assessing students' abilities in English at UEA.

This study was carried out at UEA for two months starting from September $21^{\text {st }}$ through October $21^{\text {st }}, 2015$ for the students' first group, and from January $16^{\text {th }}$ to February $20^{\text {th }}, 2016$ for a catch-up for the sake of the second group which registered lately.

The community of the study was 780 subjects ( 259 female and 521 male).The sample of the study consisted of 750 students (259 female and 491 male) in first year undergraduate classes at UEA/2015-2016. As for their respective nationalities, there were 737 Congolese ( 252 female plus 485 male), 8 Rwandans ( 5 female plus 3 male), and 5 Cameroonians ( 2 female plus 3 male). These 750 subjects formed about $96.15 \%$ of the total number community. The sample was randomly selected from all the faculties of UEA. A few students $(780-750=30$ students or $3.85 \%$ ), who did not regularly attend English classes, were rejected by this research.

A Placement test was addressed before the start of the English course in order to identify different levels of students. Because of a big number of students enrolled in these classes, only written exercises pertaining to Identification, Vocabulary words, Grammar and Composition were given them for two hours maximum.

Identification exercise consisted of identifying students' names, nationalities, 
places and duration of studying English. Vocabulary words were in relation to numbers, gender, school materials, giving directions and clothes. Grammar section was related to the use of comparative and superlative of adjectives, conditional clauses, prepositions and past tenses. The composition exercise was based on vocabulary knowledge, grammar, spelling, content or the substance, style and length (of three to six full and correct sentences). The topic given them was about the "importance of English" in their town or country. The placement test was invigilated by Assistant lecturers and done by these students in six classrooms at the school of Agronomy.

Thus, it was expected that students could be placed at different English levels according to the following grading scale: Beginner one level: 0\% - 29\% marks; Beginner two: 30\% - 49\% marks; Intermediate one: 50\% - 69\% marks; Intermediate two: 70\% - 89\% marks; Advanced level: 90\% - 100\% marks.

With class observations during teaching the English course, the following four English basic skills have been taken in account: listening, speaking, writing and reading. English language basic skill assessment forms prepared by the teachers of English were analysed and compared according to the four indicators below: Outstanding, Good, Average and Below average (cf. Appendix 1).

The collected data were transformed into tables and calculated in percentage to facilitate the interpretation.

\section{Presentation and Analysis of the Results}

In this section, placement test results, challenges faced by learners of English in first year undergraduate classes $\left(1^{\text {st }}\right.$ semester/2015-2016) have been presented and analysed. Before attending the English course, students sat for the placement test (cf. results in Table 1).

\subsection{Placement Test Results}

The placement test was necessary for registering fresh students at different levels at UEA.

Table 1 demonstrates four English levels organized at UEA: Beginner One (270 Students $=36 \%)$, Beginner Two (175 Students $=23.33 \%)$, Intermediate One $(180$ Students $=24 \%)$, and Intermediate Two (125 Students $=16.67 \%)$. There

Table 1. Student number at different English levels ( $1^{\text {st }}$ Semester/2015-2016 at UEA).

\begin{tabular}{cccc}
\hline & \multicolumn{2}{c}{ STUDENTS } & \multirow{2}{*}{ TOTAL } \\
\cline { 2 - 3 } ENGLISH LEVEL & FEMALE & MALE & 270 \\
Beginner One & 76 & 194 & 175 \\
Beginner Two & 65 & 110 & 180 \\
Intermediate One & 74 & 106 & 125 \\
Total & 44 & 81 & 750 \\
\hline
\end{tabular}

Source: Based on Placement test results (September 2015 and February 2016 at UEA/Bukavu, DR Congo) 
was no Advanced level. Female students are 259/750 and represent $34.53 \%$ against 491 male ones or $65.47 \%$.

Actually, it is necessary to investigate on challenges faced by the focused learners of English before identifying their most difficult basic skill.

\subsection{Challenges Faced by Learners of English in First Year Undergraduate Classes at UEA (1 ${ }^{\text {st }}$ Semester/2015-2016)}

Tables 2-5 display challenges faced by learners of English in first year undergraduate classes at UEA in the first semester/2015-2016.

\subsubsection{Listening Skill Difficulties}

Listening to the teachers occurred before speaking, writing and reading English. That is why listening difficulties are identified first in Table 2.

Table 2 demonstrates linking verbs and words, elision and sentence stress as listening skill difficulties: outstanding with 133/750 students (17.73\%), good: $366 / 750$ students (48.80\%), average: $215 / 750$ students (28.67\%), below average: $36 / 750$ students $(4.80 \%)$.

The second basic skill problems to be displayed are speaking ones (Table 3).

Table 2. Listening skill difficulties ( $1^{\text {st }}$ Semester/2015-2016).

\begin{tabular}{cccccc}
\hline \multirow{2}{*}{ ENGLISH LEVEL } & \multicolumn{4}{c}{$\begin{array}{c}\text { LISTENING SKILL DIFFICULTIES (identified through linking verbs } \\
\text { and words, elision and sentence stress) }\end{array}$} & TOTAL \\
\cline { 2 - 5 } & OUTSTANDING & GOOD & AVERAGE & BELOW AVERAGE & \\
\hline Beginner One & 27 & 136 & 93 & 14 & 270 \\
Beginner Two & 97 & 68 & 10 & 00 & 175 \\
Intermediate One & 5 & 80 & 81 & 14 & 180 \\
Intermediate Two & 4 & 82 & 31 & 8 & 125 \\
Total & 133 & 366 & 215 & 36 & 750 \\
\hline
\end{tabular}

Source: English basic language skill assessment forms (September 2015 and February 2016 at UEA/Bukavu, DR Congo).

Table 3. Speaking skill difficulties ( $1^{\text {st }}$ Semester 2015-2016)

\begin{tabular}{|c|c|c|c|c|c|}
\hline \multirow{2}{*}{ ENGLISH LEVEL } & \multicolumn{4}{|c|}{$\begin{array}{l}\text { SPEAKING SKILL DIFFICULTIES (=a little vocabulary knowledge } \\
\text { and mother tongue interference) }\end{array}$} & \multirow{2}{*}{ TOTAL } \\
\hline & OUTSTANDING & GOOD & AVERAGE & BELOW AVERAGE & \\
\hline Beginner One & 25 & 140 & 88 & 17 & 270 \\
\hline Beginner Two & 96 & 66 & 13 & 00 & 175 \\
\hline Intermediate One & 3 & 42 & 50 & 85 & 180 \\
\hline Intermediate Two & 4 & 83 & 33 & 5 & 125 \\
\hline Total & 128 & 331 & 184 & 107 & 750 \\
\hline
\end{tabular}




\subsubsection{Speaking Skill Difficulties}

Speaking skill difficulties such as a little vocabulary knowledge and mother tongue interference are included in the following table.

The above findings reveal that speaking difficulties related to a little vocabulary knowledge and mother tongue interference are faced by students of first year undergraduate classes as follows: outstanding: 128/750 students (17.07\%), good: $331 / 750$ students (44.13\%), average: $184 / 750$ students (24.53\%), below average: $107 / 750$ students (14.27\%). This last percentage shows that the rate of low average students increases in English speaking skill. This difference will be justified after analysing all tables.

\subsubsection{Writing Skill Difficulties}

The following table deals with writing difficulties experienced by students in first year undergraduate classes at UEA.

Table 4 findings show that the target students also encounter redundancy and misspelling words of the English composition as writing problems: outstanding: 79/750 students (10.53\%), good: 359/750 students (47.87\%), average: $264 / 750$ students (35.20\%), below average: $48 / 750$ students (6.40\%).

After listening, speaking and writing skills assessments, here are some reading skill challenges met by these students.

\subsubsection{Reading Skill Difficulties}

The last English basic language skill difficulties are assessed in Table 5.

Table 5 demonstrates that mispronunciation of English words and/or the use of a wrong word that sounds similar are reading difficulties experienced by first year undergraduate classes at UEA: outstanding: 90/750 students (12\%), good: 350/750 students (46.67\%), average: 263/750 students (35.06\%), below average: $47 / 750$ students (6.27\%).

Considering all above results in Table 2 up to Table 5, it is obvious that the speaking skill evaluated with the highest failure rate (14.27\%) was the most difficult skill for first year undergraduate students at UEA ( $1^{\text {st }}$ semester/2015-2016). This is due to the following factors.

Table 4. Writing skill difficulties ( $1^{\text {st }}$ Semester/2015-2016).

\begin{tabular}{ccccccc}
\hline \multirow{2}{*}{ ENGLISH LEVEL } & \multicolumn{3}{c}{$\begin{array}{c}\text { WRITING SKILL DIFFICULTIES (redundancy and misspelling } \\
\text { words of the English composition) }\end{array}$} \\
\cline { 2 - 5 } & OUTSTANDING & GOOD & AVERAGE & BELOW AVERAGE & \\
\hline Beginner One & 21 & 125 & 108 & 16 & 270 \\
Beginner Two & 54 & 103 & 18 & 00 & 175 \\
Intermediate One & 4 & 68 & 80 & 28 & 180 \\
Intermediate Two & 00 & 63 & 58 & 4 & 125 \\
Total & 79 & 359 & 264 & 48 & 750 \\
\hline
\end{tabular}

Source: English basic language skill assessment forms (September 2015 and February 2016 at UEA/Bukavu, DR Congo). 
Table 5. Reading difficulties ( $1^{\text {st }}$ Semester/2015-2016).

\begin{tabular}{cccccc}
\hline \multirow{2}{*}{ ENGLISH LEVEL } & \multicolumn{2}{c}{$\begin{array}{c}\text { READING SKILL DIFFICULTIES (mispronunciation of English } \\
\text { words and/or the use of a wrong word that sounds similar) }\end{array}$} & \multirow{2}{*}{ TOTAL } \\
\cline { 2 - 5 } & OUTSTANDING & GOOD & AVERAGE & BELOW AVERAGE & \\
\hline Beginner One & 20 & 121 & 112 & 17 & 270 \\
Beginner Two & 65 & 97 & 13 & 00 & 175 \\
Intermediate One & 3 & 76 & 74 & 27 & 180 \\
Intermediate Two & 2 & 56 & 64 & 3 & 125 \\
Total & 90 & 350 & 263 & 47 & 750 \\
\hline
\end{tabular}

Source: English basic language skill assessment forms (September 2015 and February 2016 at UEA/Bukavu, DR Congo).

\subsection{Some Factors of English Speaking Skill Difficulties at UEA (1 ${ }^{\text {st }}$ Semester/2015-2016)}

According to CT Buhendwa R.J. (2018: p.164), factors causing English speaking skill difficulties are low-backgrounds of learners, shyness and lack of interest in English language activities.

Most fresh students came from different high schools where English course was not taught well. Others went out while their teacher of English entered the classroom. "Being afraid of making mistakes and because their classmates could laugh at them, some students were shy". Finally, a big number of students did not attend English clubs and the Language Resource Centre organized at UEA respectively for practice and training.

\section{Discussion of the Results}

Table 1 dealt with placement test results which revealed that four English levels were organized at UEA: Beginner One, Beginner Two, Intermediate One and Intermediate Two. This finding, coupled with Robin M. Lisboa's study (2004: p. 4, p. 6), highlights that in order to promote the levels of English language proficiency, it is recommended to divide the group of English learners into different levels. As there was no Advanced level at UEA during the academic year 2015-2016, it is possible that UEA could not organize that training level for two or three students only. They could not afford academic fees for their own classroom. So they entered Intermediate II level, which was one of large classes also.

Table 2 presented English listening difficulties in the way below: outstanding: $17.73 \%$, good: $48.80 \%$, average: $28.67 \%$, below average: $4.80 \%$. Even Kazouz Ismail (2015: p. 2), who carried out an investigation of listening difficulties at UKMO in Algeria, mentioned that Algerian second year students of English faced different problems while listening to English. These problems could be related to listening material, linguistic aspects, lack of concentration, psychological factors, and physical setting. On their sides, Wajiha Kanwal and Fauzia Khurshid (2012: p. 332) pointed out that students (75\%) in India wanted to listen in English but $62 \%$ could understand when their teacher spoke this last language. 
Table 3 demonstrated speaking difficulties with the rate below: outstanding: $17.07 \%$, good: $44.13 \%$, average: $24.53 \%$, below average: $14.27 \%$. This finding is consistent with Katherine E. Garrett's (2006: p. 5) and Ming Chang's investigations (2011: p. 7) respectively showing that immigrants and refugees in America and Taiwanese students experienced also English speaking skill problems. These last ones arose against the first group especially "when they went to the public library, saw a doctor, at their child's school, and when lost and seeking directions".

Moreover, mother tongue interference was identified as another factor of speaking skill difficulties. This finding is consistent with an investigation conducted in Thailand by Sripathum Noom-Ura (2013: p. 5) showing that "students were thinking in Thai before translating to English". Even Samira Al Hosni (2014: p. 23) argued that Arabians Young EFL Learners use their mother tongue because it is easier and because they feel less exposed if they are speaking it.

Table 4 showed writing difficulties (outstanding: $10.53 \%$, good: $47.87 \%$, average: $35.20 \%$, below average: $6.40 \%$ ). This finding copes with Sripathum Noom-Ura's research (2013: p. 5) which demonstrated that in Thailand, students had problems with writing, with listening and pronunciation too.

Table 5 indicated reading difficulties in the following way: outstanding: $12 \%$, good: $46.67 \%$, average: $35.06 \%$, below average: $6.27 \%$. This finding copes with Mike King's survey (available on

http://www.readfaster.com/education_stats.asp, https://www.lrs.org/2007/11/20/who_knew_-_literacy_and_reading_habits/, downloaded on April 8, 2016) demonstrating that in North American nearly 60\% of all adults never read another book after high school and more than $80 \%$ did not read a single book in 2008 .

\section{Conclusion and Recommendations}

To conclude, a placement test was organized before the teaching of the English course in order to identify students' different levels. Results revealed that Beginner One, Beginner Two, Intermediate One and Intermediate Two were the four English levels of the first year undergraduate students at UEA/2015-2016. Contrary to our expectations, there was no Advanced level.

Thanks to the class observations, some English language skill difficulties were identified: a little vocabulary knowledge and mother tongue interference as speaking skill difficulties, redundancy and misspelling words of the English composition for the writing skill challenges, mispronunciation of English words or the use of a wrong word that sounds similar as reading skill difficulties; and linking verbs and words, elision and sentence stress in listening skill were the major challenges faced by these students.

Finally, thanks to analytical and comparative methods, speaking skill was rated as the students' biggest challenge (with the highest below average rate: $14.27 \%$ ), followed by writing (below average: $6.40 \%$ ), reading (below average: 
$6.27 \%$ ), and listening (below average: $4.80 \%$ ). These findings seem to show that the first year undergraduate students lacked skills in speaking the most, which led the researcher to identify speaking as their most severe problem at UEA.

The main causes of such a challenge were: low-backgrounds of learners, shyness and lack of interest in English language activities. These findings meet our hypothesis according to which different factors cause this challenge encountered by learners of English in the first year undergraduate classes in the first semester/2015-2016 at UEA.

Further studies are therefore necessary to determine "How to increase French speaking students' motivation in learning English as a Foreign Language”.

Based on the findings of the research, some recommendations, which may help students to reduce more and more those difficulties, are made below:

1) Teachers of English at UEA should try to ask students to read a lot of English books in order to get at least ten to twenty new words a day. They should inspire shy students with self-confidence and self-esteem: for example, they should encourage them to choose their partners to practice English. Then after, the Teacher will ask their classmates to clap hands for them. All teachers of English at UEA should also use audiovisual aids which could allow students to listen to the stress and intonation of English-native speakers. For this reason, technical supports (internet access, projectors, audiovisuals and loud speakers) should be multiplied and provided in every classroom at UEA.

2) As the most difficult skill faced by the first year undergraduate students at UEA, speaking skill should be improved by reciting memory verses which might be applied to each faculty, by making presentations in classrooms and in English clubs, by holding dialogues and debates, by asking and answering oral comprehension questions, by using collocations related to each study domain. Students with low-backgrounds should attend evening classes at the Language Resource Centre of UEA for more practice; briefly, to improve their ability to speak good English.

3) UEA should keep on giving first year undergraduate fresh students in all faculties the placement test followed by a whole month intensive English course (for instance, from September 15 up to October 15 or from October 1 to 31).

4) The Government of DR Congo should add an "Elementary English Course" to the National Curriculum, via the Ministry of Primary and Secondary Education. This new programme could allow the Congoleses to learn English from bottom to top, following the example of French language teaching in this country.

\section{Conflicts of Interest}

The author declares no conflicts of interest regarding the publication of this paper.

\section{References}

Al Hosni, S. (2014). Speaking Difficulties Encountered by Young EFL Learners. Interna- 
tional Journal on Studies in English Language and Literature (IJSELL), 2, 22-30. https://www.researchgate.net/publication/270340628_Speaking_Difficulties_Encounter ed_by_Young_EFL_Learners

Buhendwa, R. J. (2018). Challenges Faced by Teachers of English in First Year Undergraduate Classes at U.E.A., Bukavu, D.R. Congo. European Journal of Education Studies, 5, 159-171.

Chang, M. (2011). Factors Affecting the Implementation of Communicative Language Teaching in Taiwanese College English Classes. English Language Teaching, 4, 3-12.

Garrett, K. E. (2006). Living in America: Challenges Facing New Immigrants and Refugees (p. 5). Lake Snell Perry Mermin/Robert Wood Johnson Foundation.

Kazouz, I. (2015). An Investigation of Listening Problems Encountered by EFL Learners. A Case Study of Second Year License of English at UKMO. Ouargla: KasdiMerbah University.

Lisboa, M. R. (2004). English Language Proficiency Standards for English Language Learners $(K-12)$ (pp. 4, 6). Illinois: Illinois State Board of Education.

Mintz, S. (n.d.). The Fundamentals of College and University Teaching (p. 39). Columbia, ND: Columbia University.

https://gsas.columbia.edu/sites/default/files/inline-files/GSAS_fundamentals_handboo k.pdf

Noom-Ura, S. (2013). English-Teaching Problems in Thailand and Thai Teachers' Professional Development Needs. English Language Teaching, 6, 139-147.

https://doi.org/10.5539/elt.v6n11p139

Oluwayemisi, F. F. (2015). Tackling the Challenges of Teaching English Language as Second Language (ESL) in Nigeria. IOSR Journal of Research \& Method in Education (IOSR-JRME), 5, 26-30.

Reddy, P. S. (2012). Problems in Teaching/Learning English as a Second Language in India. Language in India. Strength for Today and Bright Hope for Tomorrow, 12, 781-790.

Wajiha, K., \& Fauzia, K. (2012). University Students' Difficulties in Learning English Language Skills, in Language in India. Strength for Today and Bright Hope for Tomorrow, 12, 332 . 


\section{Appendix I: Sample of English Language Basic Skill Assessment}

EVANGELICAL UNIVERSITY IN AFRICA (UEA)

FACULTY OF

YEAR AND ENGLISH LEVEL

Table A1. English language basic skill assessment.

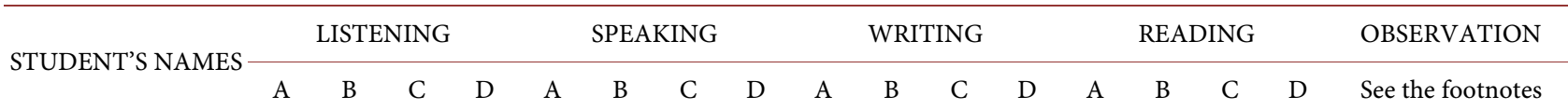

$\begin{array}{lllllllllllllllll}\text { TOTAL } & 1 & 1 & 1 & 0 & 0 & 2 & 0 & 1 & 0 & 0 & 2 & 1 & 0 & 0 & 1 & 2\end{array}$

Source: Notes: ${ }^{\star} \mathrm{A}=$ Outstanding; ${ }^{*} \mathrm{~B}=$ Good; ${ }^{\star} \mathrm{C}=$ Average; ${ }^{*} \mathrm{D}=$ Below average. 